\title{
Genetic and symbiotic characterization of rhizobia nodulating legumes in a mining area
}

\section{in southeast Brazil}

\author{
Bruna Daniela Ortiz Lopez ${ }^{\circledR}$, Anita Fernanda dos Santos Teixeira®, Daniele Cabral Michel®, Amanda Azarias Guimarães ${ }^{\circledR}$, Amanda \\ Monique da Costa ${ }^{\circledR}$, Juliana Santos Costa ${ }^{\circledR}$, Marcela de Souza Pereira®, Bárbara Luyse Marques Duarte ${ }^{\circledR}$, Fatima Maria de Souza \\ Moreira*(1)
}

Universidade Federal de Lavras - Depto. de Ciência do Solo - Setor de Biologia, Microbiologia e Processos Biológicos do Solo, C.P. 3037 - 37200-900 - Lavras, MG - Brasil.

*Corresponding author <fmoreira@ufla.br>

Edited by: Fernando Dini Andreote

Received August 10, 2020

Accepted December 02, 2020
ABSTRACT: Identification and selection of nitrogen-fixing bacterial strains for inoculation into native leguminous tree species can assist in the recovery of degraded areas. Additionally, native strains from these areas are genetic resources adapted to these conditions and are thus suitable for selection. The aim of this study was to symbiotically and genetically characterize 18 bacterial strains from the Rhizobium and Bradyrhizobium genera isolated from Machaerium nyctitans, Platypodium elegans, and Ormosia arborea grown in a nursery in an iron mining area. Three experiments were conducted under axenic conditions in a greenhouse. The nodulation capacity of the strains was evaluated by the number (NN) and dry matter (NDM) of nodules. Symbiotic efficiency was evaluated based on the following parameters: SPAD index (SPAD), shoot dry matter (SDM), root dry matter (RDM), and total dry matter (TDM) of the plants, relative efficiency (RE), shoot nitrogen content (SNC), and total nitrogen content in the plant (TNC). The atpD and gyrB housekeeping genes and the nifH gene were sequenced for phylogenetic analysis, and the nodC and nodD symbiotic genes of the strains were amplified. Out of the 18 strains, 16 were authenticated by nodulation capacity in the species of origin. The SPAD variable allowed for the detection of differences between treatments before the SDM. Additionally, the SPAD index showed correlation with TNC, and the strain Bradyrhizobium sp., UFLA01-839, which may represent a new species, was outstanding in Machaerium nyctitans. The nifH, nodD, and nodC genes were detected in UFLA01-839.

Keywords: housekeeping genes, symbiotic genes, authentication, symbiotic efficiency

\section{Introduction}

Native leguminous tree species can be allies in the recovery of degraded areas since they do not pose the same ecological risk as non-native species, and they have desirable characteristics, such as biological nitrogen fixation as a result of their symbiosis with rhizobia strains (Sattler et al., 2018). However, rhizobia able to efficiently nodulate, i.e., establish efficient symbiosis, with a given legume host species are not always present in the soil, especially under stressful soil conditions such as those in a mining area or in an inert substrate under nursery conditions. Thus, efficient strains compatible with target legume species must be selected. Machaerium nyctitans (Vell.) Benth, Platypodium elegans Vogel, and Ormosia arborea (Vell.) Damage is commonly found by flora surveys in Brazil (Silva et al., 2015; Oliveira et al., 2018; Vale et al., 2018). Although there are reports of nodulation in these and various forest species due to rhizobia (Faria et al., 1989; Moreira et al., 1992; Sprent and Parsons, 2000), nodulation can be induced by inefficient strains, i.e., strains that do not fix nitrogen in symbiosis with the species. Therefore, it is necessary to select strains that are efficient for each one of these forest species of interest due to the possible specificity between symbionts. To obtain strains, it is necessary to isolate these microorganisms from the soil or root nodules of leguminous plants of interest, characterize them phenotypically and genotypically, authenticate them under axenic conditions in the species of origin, and confirm their symbiotic efficiency (Moreira, 2008).

With the advances in molecular techniques, genetic characterization of these strains has become increasingly accessible for taxonomic classification as well as for corroborating the functionality of the strains related to symbiotic $\mathrm{N}_{2}$ fixation (Zou et al., 2016). Within this context, the aim of this study was to i) authenticate and verify the symbiotic efficiency of 18 strains inoculated into seedlings of their respective host species in a greenhouse, and evaluate the possible morpho-physiological benefits in these species; ii) genetically characterize these strains by sequencing of housekeeping genes ( $a t p D$ and gyr $B$ ) and comparing them phylogenetically with sequences of type strains; iii) analyze the presence of specific genes related to nitrogen fixation $(n i f H)$ and nodulation $(\operatorname{nod} C$ and $\operatorname{nod} D)$ to obtain strains with biotechnological potential for the recommendation as inoculants.

\section{Materials and Methods}

\section{Origin of the strains}

Eighteen strains used in this study were isolated from nodules taken from forest seedlings of Machaerium nyctitans (7), Platypodium elegans (8), and Ormosia 
arborea (3) produced in nurseries in mining areas in the municipalities of Nova Lima $\left(20^{\circ} 7^{\prime} 5^{\prime \prime} \mathrm{S}, 43^{\circ} 57^{\prime} 1^{\prime \prime} \mathrm{W}\right.$, altitude $742 \mathrm{~m}$ ) and Sabará (19 $51^{\prime} 44^{\prime \prime} \mathrm{S}, 43^{\circ} 47^{\prime} 38^{\prime \prime} \mathrm{W}$, altitude $705 \mathrm{~m}$ ) in the state of Minas Gerais. Isolation and strain characterization were performed in solid 79 culture medium (Fred and Waksman, 1928). All the strains previously identified at the genus level by sequencing of the $16 \mathrm{~S}$ rRNA gene were analyzed phylogenetically (Table 1). The BR4101 strain of Ormosia nitida was also tested.

\section{Authentication and symbiotic efficiency}

Three experiments were conducted in a greenhouse. The aim of each experiment was to authenticate the strains, i.e., prove they are able to nodulate the legume species from which they were isolated, and test the symbiotic efficiency of each strain in its species of origin. The seeds of $M$. nyctitans and $P$. elegans were surface disinfected with $2 \%$ hypochlorite for $3 \mathrm{~h}$, without the need for breaking dormancy. For O. arborea, dormancy was broken through immersion in sulfuric acid P.A. for $15 \mathrm{~min}$. After that, seeds of the three species were washed in sterile distilled water for 15 more min to eliminate residues. The seeds were placed in trays containing sterile sand for germination and were moistened with sterile distilled water. After seedlings formed, they were transplanted in $250 \mathrm{~cm}^{3}$ seedling plug pots containing a $1: 1(\mathrm{v} / \mathrm{v})$ mixture of sterile sand and vermiculite. At the time of transplanting, the seedlings were inoculated with $1 \mathrm{~mL}$ of inoculant of each one of the 18 bacterial strains in the respective host species, and the BR4101 strain was inoculated into the three species. For preparation of the inoculants, each strain was grown in liquid 79 medium in an incubation chamber shaken at $150 \mathrm{rpm}$. The cultivation time of the inoculants was determined according to the period for growth of each genus to achieve the log phase: six days for the Bradyrhizobium strains (slow growth), and three days for the Rhizobium strains (fast growth). The treatments of the three experiments included absolute control - without inoculation and low mineral nitrogen content (LN); control without inoculation and with high mineral nitrogen content $(\mathrm{HN})$; control with a bacterial strain from Ormosia nitida (BR4101) [efficient for this species (Faria and Uchôa, 2007)] and identified by sequencing of $16 \mathrm{SrRNA}$ as belonging to Ochrobactrum (Moreira and Siqueira, 2006); and treatments inoculated with the strains from each forest species (Table 1), all with low mineral $\mathrm{N}$ content. The strain BR4101 was tested on all the leguminous tree species because there are no strains approved as inoculants by the Brazilian Ministry of Agriculture (MAPA) for any of the species studied (MAPA, IN SDA 2011).

The seedling plug pots received fertigation $(50 \mathrm{~mL}$ per plug pot twice a week) through the application of a nutrient solution (Hoagland and Arnon, 1950) modified according to nitrogen content: $52.5 \mathrm{mg} \mathrm{N} \mathrm{L}^{-1}$ for the $\mathrm{HN}$ treatment, and $5.25 \mathrm{mg} \mathrm{N} \mathrm{L}^{-1}$ for the LN treatment and for the treatments inoculated with the strains as described by Guimarães et al. (2012).

The experiments were evaluated at 60,90, and 150 days after transplanting, considering the size of the seeds for M. nyctitans, P. elegans, and O. arborea (smaller to

Table 1 - Information on strains (UFLA code) used in the present study: forest species from which they were isolated, characteristics in 79 culture medium, identification at the genus level, and accession number of 16S rRNA sequence in the NCBI database.

\begin{tabular}{|c|c|c|c|c|}
\hline Strain & Species of origin & Culture Group* & Genus** & Accession code of the 16 SrRNA \\
\hline UFLA01-814 & \multirow{7}{*}{ Machaerium nyctitans } & $\mathrm{LAL}$ & Bradyrhizobium & KY713267 \\
\hline UFLA01-834 & & $\mathrm{LAL}$ & Bradyrhizobium & KY713278 \\
\hline UFLA01-839 & & $\mathrm{LAL}$ & Bradyrhizobium & KY713270 \\
\hline UFLA01-860 & & $I A L$ & Bradyrhizobium & KY713266 \\
\hline UFLA01-883 & & $\mathrm{LAL}$ & Bradyrhizobium & KY713289 \\
\hline UFLA01-1164 & & $\mid A L$ & Bradyrhizobium & MT458665 \\
\hline UFLA01-1172 & & RA & Rhizobium & MT458666 \\
\hline UFLA01-1147 & \multirow{3}{*}{ Ormosia arborea } & RAL & Rhizobium & MT458664 \\
\hline UFLA01-1156 & & RN & Rhizobium & MT458655 \\
\hline UFLA01-1161 & & $\mid A L$ & Bradyrhizobium & MT458656 \\
\hline UFLA01-874 & \multirow{8}{*}{ Platypodium elegans } & LAL & Bradyrhizobium & KY713261 \\
\hline UFLA01-1127 & & $\mathrm{RN}$ & Rhizobium & MT458658 \\
\hline UFLA01-1128 & & RA & Rhizobium & MT458659 \\
\hline UFLA01-1129 & & RA & Rhizobium & MT458660 \\
\hline UFLA01-1132 & & IAL & Bradyrhizobium & MT458657 \\
\hline UFLA01-1134 & & RA & Rhizobium & MT458661 \\
\hline UFLA01-1136 & & $\mid A L$ & Bradyrhizobium & MT458662 \\
\hline UFLA01-1137 & & $\mathrm{RA}$ & Rhizobium & MT458663 \\
\hline
\end{tabular}

${ }^{*} \mathrm{IAL}=$ intermediate growth (from four to six days) and alkalization of the medium; LAL = slow growth (seven days or more) and alkalization of the medium, RA = rapid growth (one to three days) and acidification of the medium, $\mathrm{RN}=$ rapid growth without change in $\mathrm{pH}$. ${ }^{* *} \mathrm{Genus}$ of strains obtained through sequencing of the 16S rRNA gene. 
larger, respectively). This is because the larger the seed, the greater the energy reserve and the longer the time for cotyledon senescence, which may affect the beginning of the symbiosis establishement, i.e., the appearance and functionality of the nodules. The Soil Plant Analysis Development (SPAD) index was determined 60 days after transplanting (SPAD1) for all the forest species studied. For P. elegans and O. arborea, a second measurement was taken at the end of the experiment 190 and 150 days, respectively) (SPAD2). After collection, the following parameters were evaluated: number of nodules $(\mathrm{NN})$, nodule dry matter (NDM), shoot dry matter (SDM), root dry matter (RDM), total dry matter (TDM) by the sum of SDM and RDM, relative efficiency (RE) calculated by the expression $\mathrm{RE}=$ (SDM of inoculated treatment/ SDM of HN control) $\times 100$, shoot nitrogen content in $g$ $\mathrm{N} g$ per plant $(\mathrm{SNC})$, and total nitrogen content of the plant in $\mathrm{g} \mathrm{N}$ per plant (TNC). SNC was evaluated by the semi-micro Kjeldahl method (Kirk, 1950) and used for calculation of the TNC by the expression SNC $\times$ SDM.

\section{DNA extraction}

Genomic DNA of the strains was extracted using the Wizard ${ }^{\circledR}$ Genomic DNA Purification kit, following the manufacturer's recommendations. The quality and concentration of the extracted DNA was analyzed using a Colibri spectrometer.

\section{Amplification and sequencing of housekeeping genes $(a t p D$ and gyr $\mathrm{B})$}

The gyrB gene was amplified using the primers $343 \mathrm{~F} \quad\left(5^{\prime}\right.$ TTCGACCAGAAYTCCTAYAAGG $\left.3^{\prime}\right)$ and 1043R (5' AGCTTGTCCTTSGTCTGCG $\left.3^{\prime}\right)$. The $a t p D$ gene was amplified using the primers $352 \mathrm{~F}$ (5' AGCTTGTCCTTSGTCTGCG $\left.3^{\prime}\right)$ and 871R $\left(5^{\prime}\right.$ AGMGCCGACACTTCMGARCC 3') (Gaunt et al., 2001; Martens, 2007). The PCR reaction and amplification of the gyrB gene followed the methodology described by Sá et al. (2019), which was also used for the atpD gene. The DNA fragments obtained from the PCR products were verified in $1 \%(\mathrm{w} / \mathrm{v})$ agarose gel and visualized in a UV transilluminator. The PCR products were sequenced by Wenseq in a 3500 xLGenetic analyzer (Applied Biosystems) sequencer with 24 50-cm capillaries and Pop7 polymer.

\section{PCR amplification of the nifH, nodC, and nodD symbiotic genes}

The nifH gene was amplified using the primers nifHF (5' AAAGGYGGWATCGGYAARTCCACCAC $3^{\prime}$ ) and nifHR (5' TTGTTSGCSGCRTACATSGCCATCAT 3') with Promega GoTaq DNA Polymerase (500 U-M3005), and the thermal cycler was used under the conditions described in Rösch et al. (2002). The PCR products were directly sequenced on both strands. The nodC gene was amplified using the primers 540F $15^{\prime}$ TGATYGAYATGGARTAYTGGCT $\left.3^{\prime}\right)$ and 1160R $\left(5^{\prime}\right.$ CGYGACARCCARTCGCTRTTG 3') with Promega GoTaq DNA Polymerase (500 U-M3005), and the thermal cycler was used under the conditions described in Sarita et al. (2005). The nodD gene was amplified using the primers nodDF (5' GATYGTCATGAAATCKGAGAG 3') and nodDR (5' TCGATAGAANACATCCACACGAT 3') with Promega GoTaq DNA Polymerase (500 U-M3005), and the thermal cycler was used under the conditions described in Sterner and Parker (1999). The nifH, nodC and nodD bands were visualized in $1 \%(\mathrm{w} / \mathrm{v})$ agarose gel through the UV transilluminator.

\section{Phylogenetic analysis}

The sequences quality and contigs assembly of the housekeeping (atpD and gyrB) and symbiotic (nifH) genes were verified using the BioNumerics 7.6 software system. The MUSCLE (Edgar, 2004) multiple alignment algorithm was used to align the sequences. Phylogenetic trees were constructed on the MEGA 7 software (Kumar et al., 2016) by the neighbor-joining (NJ) method (Saitou and Nei, 1987) using the Kimura 2 parameter (Kimura, 1980) with bootstrap of 1000 replications. The sequences used in phylogenetic analysis were those that have a base pair number of 205 for the nifH gene for both Rhizobium and Bradyrhizobium, as well as 210 and 207 for the gyrB and 336 and 352 for the atpD genes, for Rhizobium and Bradyrhizobium, respectively. Sequences of type strains of Bradyrhizobium and Rhizobium available in the Genbank (National Center for Biotechnology Information, NCBI) that had at least $95 \%$ similarity with the sequences studied (calculated by BLAST) were included in the phylogenetic analysis. Each phylogenetic analysis was evaluated with mathematical language to obtain the percentage of dissimilarity between sequences and their similarity, calculated by the expression $(1-\mathrm{x}) \times 100$, where " $\mathrm{x}$ " is the value of dissimilarity obtained by comparisons between the base pairs of each sequence.

\section{Statistical analysis}

A completely randomized experimental design (CRD) was used, with five replications for the experiment with $P$. elegans and three replications for experiments with $M$. nyctitans and $O$. arborea. Analysis of variance (ANOVA) was performed for the variables RDM, SDM, TDM, RE, SPAD1, SPAD2, SNC, and TNC, and their means were compared with the HN and LN controls by the Dunnett test at $5 \%$ probability using the R software program in the gvlma (Pena and Slate, 2006), agricolae (Mendiburu, 2017), and asbio (Ken, 2020) packages. In addition, Pearson linear correlation analysis was applied to all the variables analyzed in the symbiosis experiments, using the biotools package in the R software program (Silva et al., 2017). 


\section{Results}

\section{Authentication and symbiotic efficiency}

In the $\mathrm{LN}$ and $\mathrm{HN}$ treatments, there was no nodule formation, confirming the absence of contamination in the experiments. The strain recommended for inoculation in $O$. nitida (BR4101) exhibited positive nodulation in the experiments with $O$. arborea and $M$. nyctitans. However, nodulation of this strain in P. elegans was not detected.

In the experiment with $M$. nyctitans, of the seven strains tested, all nodulated in the species of origin, six of Bradyrhizobium and one of Rhizobium (Table 2). Among these strains, it was possible to amplify the nifH gene of Bradyrhizobium UFLA01-814, UFLA01-834, UFLA01-839, UFLA01-860, UFLA01-883 and UFLA011164, and Rhizobium UFLA01-1172; the nodC gene of Bradyrhizobium UFLA01-814 and UFLA01-883; and the nodD gene of Bradyrhizobium UFLA01-834, UFLA01839, and UFLA01-883. In the experiment with $P$. elegans, of the eight strains tested, six nodulated in the species of origin, three from Bradyrhizobium and three from Rhizobium (Table 3). Among these strains, it was possible to amplify the nifH gene of Rhizobium UFLA011128 and UFLA01-1137, and Bradyrhizobium UFLA011136 and the nodD gene of Bradyrhizobium UFLA01-874 and UFLA01-1136, and Rhizobium UFLA01-1128 and UFLA01-1134. In the experiment with $O$. arborea, of the three strains tested, all nodulated in the species of

Table 2 - Performance of strains of Jacarandá bico-de-pato (Machaerium nyctitans) evaluated as regards number of nodules (NN), nodule dry matter (NDM), shoot dry matter (SDM), root dry matter (RDM), total dry matter (TDM), relative efficiency (RE), SPAD index (SPAD), shoot nitrogen content (SNC), and total nitrogen content per plant (TNC) at 60 days after sowing in an experiment in a greenhouse under axenic conditions. Mean data of three replications.

\begin{tabular}{|c|c|c|c|c|c|c|c|c|c|}
\hline $\begin{array}{l}\text { Inoculation treatment } \\
\text { (Genus*) }\end{array}$ & $\mathrm{NN}$ & NDM & SDM & RDM & TDM & RE & SPAD 1 & SNC & TNC \\
\hline & & mg per plant & - & per plant & - & $\%$ & & mg N g per plant & mg N per plant \\
\hline UFLA 01-814(B) & 25 & 2.33 & $0.23 \mathrm{Aa}^{* *}$ & $0.13 \mathrm{Aa}$ & $0.36 \mathrm{Aa}$ & $67.76 \mathrm{Aa}$ & $23.43 \mathrm{Bb}$ & $16.70 \mathrm{Bb}$ & $3.89 \mathrm{Bb}$ \\
\hline UFLA 01-834(B) & 45 & 3.67 & $0.24 \mathrm{Aa}$ & $0.12 \mathrm{Aa}$ & $0.36 \mathrm{Aa}$ & $70.18 \mathrm{Aa}$ & $24.27 \mathrm{Bb}$ & 17.37 Bb & 4.22 Bb \\
\hline UFLA 01-839(B) & 49 & 39.67 & $0.29 \mathrm{Aa}$ & $0.07 \mathrm{Aa}$ & $0.36 \mathrm{Aa}$ & $83.83 \mathrm{Aa}$ & $36.00 \mathrm{Aa}$ & $28.17 \mathrm{Aa}$ & $8.35 \mathrm{Ab}$ \\
\hline UFLA 01-860(B) & 41 & 1.67 & $0.23 \mathrm{Aa}$ & $0.11 \mathrm{Aa}$ & $0.34 \mathrm{Aa}$ & $66.07 \mathrm{Aa}$ & $25.50 \mathrm{Bb}$ & $17.50 \mathrm{Bb}$ & $3.98 \mathrm{Bb}$ \\
\hline UFLA 01-883(B) & 41 & 11.0 & $0.23 \mathrm{Aa}$ & $0.10 \mathrm{Aa}$ & $0.34 \mathrm{Aa}$ & $67.38 \mathrm{Aa}$ & $25.40 \mathrm{Bb}$ & $21.47 \mathrm{Bb}$ & $4.98 \mathrm{Bb}$ \\
\hline UFLA 01-1164(B) & 55 & 15.0 & $0.18 \mathrm{Ba}$ & $0.10 \mathrm{Aa}$ & $0.28 \mathrm{Aa}$ & $51.79 \mathrm{Ba}$ & $28.07 \mathrm{Bb}$ & $23.03 \mathrm{Bb}$ & 4.12 Bb \\
\hline UFLA 01-1172(R) & 23 & 1.33 & $0.15 \mathrm{Ba}$ & $0.07 \mathrm{Aa}$ & $0.22 \mathrm{Ba}$ & $43.37 \mathrm{Ba}$ & $25.77 \mathrm{Bb}$ & $20.23 \mathrm{Bb}$ & $2.78 \mathrm{Bb}$ \\
\hline BR4101(0) & 10 & 2.67 & $0.24 \mathrm{Aa}$ & $0.15 \mathrm{Aa}$ & $0.40 \mathrm{Aa}$ & $70.57 \mathrm{Aa}$ & $26.13 \mathrm{Bb}$ & $16.20 \mathrm{Bb}$ & $3.93 \mathrm{Bb}$ \\
\hline $\mathrm{HN}\left(52.5 \mathrm{mg} \mathrm{N} \mathrm{L}^{-1}\right)$ & 0 & 0 & $0.34 \mathrm{Aa}$ & $0.12 \mathrm{Aa}$ & $0.46 \mathrm{Aa}$ & $100 \mathrm{Aa}$ & $38.47 \mathrm{Aa}$ & $34.27 \mathrm{Aa}$ & $11.72 \mathrm{Aa}$ \\
\hline LN (5.25 mg N L-1) & 0 & 0 & $0.26 \mathrm{Aa}$ & $0.15 \mathrm{Aa}$ & $0.41 \mathrm{Aa}$ & $74.25 \mathrm{Aa}$ & $25.57 \mathrm{Bb}$ & $17.77 \mathrm{Bb}$ & $4.55 \mathrm{Bb}$ \\
\hline
\end{tabular}

${ }^{\star} \mathrm{B}=$ Bradyrhizobium, $\mathrm{R}=$ Rhizobium, $\mathrm{O}=$ Ochrobactrum; ${ }^{\star}{ }^{\star}$ Data followed by the same uppercase letter in the column do not differ from the HN treatment, and followed by the same lowercase letter in the column do not differ from the LN treatment; significant by the Dunnett test $(p<0.05)$. HN $=$ Control treatment with mineral nitrogen fertilization. $\mathrm{LN}=$ Control treatment without inoculation and with low mineral nitrogen content.

Table 3 - Performance of strains of Jacarandá do Campo (Platypodium elegans) evaluated as regards number of nodules (NN), nodule dry matter (NDM), shoot dry matter (SDM), root dry matter (RDM), total dry matter (TDM), relative efficiency (RE), SPAD index at 60 days after sowing (SPAD 1 ), SPAD index at 90 days after sowing (SPAD 2), shoot nitrogen content (SNC), and total nitrogen content per plant (TNC) in an experiment in a greenhouse under axenic conditions. Mean data of five replications.

\begin{tabular}{|c|c|c|c|c|c|c|c|c|c|c|}
\hline $\begin{array}{l}\text { Inoculation treatment } \\
(\text { Genus*) }\end{array}$ & NN & NDM & SDM & RDM & TDM & RE & SPAD 1 & SPAD 2 & SNC & TNC \\
\hline & & mg per plant & - & g per plant - & 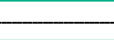 & $\%$ & & & mg N g per plant & mg N per plant \\
\hline UFLA 01-1127(R) & 1.6 & 1.4 & $0.17 \mathrm{Aa}^{\star *}$ & $0.28 \mathrm{Aa}$ & $0.45 \mathrm{Aa}$ & $115.73 \mathrm{Aa}$ & $32.67 \mathrm{Ab}$ & $26.18 \mathrm{Aa}$ & $17.22 \mathrm{Ba}$ & $2.82 \mathrm{Aa}$ \\
\hline UFLA 01-1128(R) & 0.2 & 0.6 & $0.12 \mathrm{Aa}$ & $0.20 \mathrm{Ba}$ & $0.32 \mathrm{Ba}$ & $96.74 \mathrm{Aa}$ & $33.43 \mathrm{Aa}$ & $26.03 \mathrm{Ab}$ & $22.50 \mathrm{Aa}$ & $2.43 \mathrm{Ba}$ \\
\hline UFLA 01-1129(R) & 0.0 & 0 & $0.15 \mathrm{Aa}$ & $0.28 \mathrm{Aa}$ & $0.43 \mathrm{Aa}$ & $110.11 \mathrm{Aa}$ & $33.62 \mathrm{Aa}$ & $29.10 \mathrm{Aa}$ & $19.12 \mathrm{Aa}$ & $2.98 \mathrm{Aa}$ \\
\hline UFLA 01-874(B) & 3.8 & 2.6 & $0.14 \mathrm{Aa}$ & $0.23 \mathrm{Aa}$ & $0.37 \mathrm{Aa}$ & $98.17 \mathrm{Aa}$ & $34.60 \mathrm{Aa}$ & $31.52 \mathrm{Aa}$ & $18.26 \mathrm{Aa}$ & $2.54 \mathrm{Ba}$ \\
\hline UFLA 01-1134(R) & 0 & 0 & $0.14 \mathrm{Aa}$ & $0.24 \mathrm{Aa}$ & $0.37 \mathrm{Aa}$ & $96.49 \mathrm{Aa}$ & $34.02 \mathrm{Aa}$ & $28.18 \mathrm{Aa}$ & 18.12 Ba & $2.45 \mathrm{Ba}$ \\
\hline UFLA 01-1132(B) & 0.4 & 0.2 & $0.13 \mathrm{Aa}$ & $0.35 \mathrm{Aa}$ & $0.48 \mathrm{Aa}$ & $102.7 \mathrm{Aa}$ & $38.70 \mathrm{Aa}$ & $32.14 \mathrm{Aa}$ & $20.34 \mathrm{Aa}$ & $2.70 \mathrm{Ba}$ \\
\hline UFLA 01-1137(R) & 0.4 & 1.0 & $0.17 \mathrm{Aa}$ & $0.32 \mathrm{Aa}$ & $0.49 \mathrm{Aa}$ & $116.71 \mathrm{Aa}$ & $36.62 \mathrm{Aa}$ & $32.40 \mathrm{Aa}$ & $18.60 \mathrm{Aa}$ & $3.10 \mathrm{Aa}$ \\
\hline UFLA 01-1136(B) & 14.2 & 8.4 & $0.13 \mathrm{Aa}$ & $0.27 \mathrm{Aa}$ & $0.41 \mathrm{Aa}$ & $88.05 \mathrm{Aa}$ & $35.67 \mathrm{Aa}$ & $25.90 \mathrm{Ab}$ & $11.08 \mathrm{Aa}$ & $2.25 \mathrm{Ba}$ \\
\hline BR4101(0) & 0.0 & 0 & $0.14 \mathrm{Aa}$ & $0.19 \mathrm{Ba}$ & $0.34 \mathrm{Aa}$ & $99.9 \mathrm{Aa}$ & $32.95 \mathrm{Aa}$ & $29.17 \mathrm{Aa}$ & $17.10 \mathrm{Aa}$ & $2.72 \mathrm{Aa}$ \\
\hline$\overline{\mathrm{HN}}\left(52.5 \mathrm{mg} \mathrm{N} \mathrm{L}^{-1}\right)$ & 0 & 0 & $0.16 \mathrm{Aa}$ & $0.41 \mathrm{Aa}$ & $0.57 \mathrm{Aa}$ & $94.9 \mathrm{Aa}$ & $34.33 \mathrm{Aa}$ & $33.42 \mathrm{Aa}$ & $26.64 \mathrm{Aa}$ & $3.44 \mathrm{Aa}$ \\
\hline LN (5.25 mg N L-1) & 0 & 0 & $0.15 \mathrm{Aa}$ & $0.35 \mathrm{Aa}$ & $0.50 \mathrm{Aa}$ & $94.28 \mathrm{Aa}$ & $39.20 \mathrm{Aa}$ & $34.70 \mathrm{Aa}$ & $20.74 \mathrm{Aa}$ & $3.07 \mathrm{Aa}$ \\
\hline
\end{tabular}

${ }^{*} \mathrm{~B}=$ Bradyrhizobium, $\mathrm{R}=$ Rhizobium, $\mathrm{O}=$ Ochrobactrum; ${ }^{*}$ Data followed by the same uppercase letter in the column do not differ from the HN treatment, and followed by the same lowercase letter in the column do not differ from the LN treatment; significant by the Dunnett test $(p<0.05)$. HN $=$ Control treatment with mineral nitrogen fertilization. $\mathrm{LN}=$ Control treatment without inoculation and with low mineral nitrogen content. 
origin, one of Bradyrhizobium (UFLA 01-1161) and two of Rhizobium (UFLA 01-1147 and UFLA 01-1156) (Table 4). Among these strains, it was possible to amplify the nifH gene of the strain UFLA01-1156.

On analysing the morpho-physiological variables of M. nyctitans (Table 2), the treatment inoculated with the Bradyrhizobium UFLA01-839 strain stood out in relation to the SPAD index (36.00) as it did not show any difference from the control with mineral nitrogen fertilization $(\mathrm{HN})$ (38.47) and was superior to the control without inoculation and with low nitrogen (LN) content (25.57). The SPAD index was reflected in the shoot $\mathrm{N}$ content (SNC) and in the total $\mathrm{N}$ content (TNC), with positive correlation of 0.8 $(p<0.001)$ between these variables. In addition to the SPAD and TNC index, the plants inoculated with UFLA01839 also exhibited greater nodule dry matter, which had positive correlation of 0.2 and 0.1 with SNC and TNC, respectively $(p<0.05)$. The treatment inoculated with the Rhizobium UFLA01-1172 strain exhibited relative efficiency of $43 \%$, less than all the other treatments, including the control without inoculation and with low $\mathrm{N}$ contents, which exhibited relative efficiency above $50 \%$ (Table 2). The treatments increased the RDM of the plants; however, inoculation with the strains Bradyrhizobium UFLA01-1164 and Rhizobium UFLA01-1172 did not supply the nitrogen requirements of the plants and were inferior to the HN control (Table 2).

Analysis of the morpho-physiological variables of the authentication experiment in P. elegans (Table 3) revealed no differences between the SPAD1 and SPAD2 values for the treatments and the controls, and there was no difference between the controls (HN - LN). For all the treatments, there was a reduction from SPAD1 to SPAD2 (Table 3) and both indices exhibited a positive correlation of $0.5(p<0.001)$. The treatment inoculated with the Bradyrhizobium UFLA01-1136 strain exhibited the highest NN and NDM (Table 3). Nevertheless, this was not reflected in a relative efficiency higher than that of the other treatments. The HN and LN controls were not significantly different from each other for any of the variables evaluated.
The Rhizobium UFLA 01-1156 and UFLA 01-1147 strains exhibited positive nodulation in the experiment with $O$. arborea (Table 4). The UFLA 01-1156 strain had SPAD2 and SNC values statistically similar to the HN treatment (Table 4). The highest values of SDM, SPAD, SNC, and TNC were observed in the treatment with mineral nitrogen (HN), exceeding the values of the inoculated treatments, including the value from the strain isolated from the same genus $(O$. nitida). This strain (BR4101) nodulated $O$. arborea and favored the accumulation of SDM (1.22 g per plant), with relative efficiency $(55 \%)$ similar to the control with mineral nitrogen (HN) (Table 4). The plants inoculated with the UFLA01-1156 strain (Rhizobium) obtained SPAD2 and shoot $\mathrm{N}$ content (SNC) values similar to the $\mathrm{HN}$ treatment. For the treatment inoculated with the UFLA01-1156 strain, there was positive correlation of SDM with the SNC and TNC variables, at 0.2 and 0.9, respectively $(p<0.001)$.

\section{Phylogenetic analysis}

The phylogenetic analyses of the strains by the gyrB and $a t p D$ genes corroborate identification in Rhizobium and Bradyrhizobium obtained by phylogenetic analysis of the 16S rRNA gene (Table 1).

It was possible to amplify the gyrB gene from 10 of the 18 strains, four of them belonging to Rhizobium and six to Bradyrhizobium (Figure 1A and B). Among the strains identified as Rhizobium, there was clustering of the strains UFLA 01-1134, UFLA 01-1128 and UFLA 01-1127 of $P$. elegans with $100 \%$ similarity to each other and $100 \%$ bootstrap, which were nearest to $R$. tropici CIAT899 ${ }^{\mathrm{T}}$, with similarity of $92 \%$ and $62 \%$ to bootstrap. The UFLA01-1156 strain of $O$. arborea had $96 \%$ similarity to the nearest species, $R$. leucaenae CFN $299^{\mathrm{T}}, 58 \%$ bootstrap. Among the strains identified as Bradyrhizobium, UFLA01-1164 and UFLA01-839 of $M$. nyctitans were positioned separately between themselves and from all the other type strains of Bradyrhizobium. The UFLA01-1164 strain had $97 \%$ similarity to the

Table 4 - Performance of strains of Olho-de-cabra (Ormosia arborea) evaluated as regards number of nodules (NN), nodule dry matter (NDM), shoot dry matter (SDM), root dry matter (RDM), total dry matter (TDM), relative efficiency (RE), SPAD index at 60 days after sowing (SPAD 1), SPAD index at 150 days after sowing (SPAD 2), shoot nitrogen content (SNC), and total nitrogen content per plant (TNC) in an experiment in a greenhouse under axenic conditions. Mean data of three replications.

\begin{tabular}{|c|c|c|c|c|c|c|c|c|c|c|}
\hline $\begin{array}{l}\text { Inoculation treatment } \\
(\text { Genus*) }\end{array}$ & NN & NDM & SDM & RDM & TDM & RE & SPAD1 & SPAD2 & SNC & TNC \\
\hline & & mg per plant & $g$ & per plant - & - & $\%$ & & & mg N g per plant & mg N per plant \\
\hline UFLA 01-1156(R) & 2 & 1.33 & $0.71 \mathrm{Bb}^{\star *}$ & $0.48 \mathrm{Aa}$ & $1.20 \mathrm{Bb}$ & $32.32 \mathrm{Bb}$ & $30.47 \mathrm{Aa}$ & $28.53 \mathrm{Ab}$ & $15.47 \mathrm{Ab}$ & $9.05 \mathrm{Bb}$ \\
\hline UFLA 01-1161(B) & 0.3 & 24.67 & $0.86 \mathrm{Bb}$ & $0.44 \mathrm{Aa}$ & $1.33 \mathrm{Bb}$ & $39.26 \mathrm{Bb}$ & $27.87 \mathrm{Aa}$ & $26.30 \mathrm{Bb}$ & $11.90 \mathrm{Bb}$ & $10.29 \mathrm{Bb}$ \\
\hline UFLA 01-1147 (R) & 1 & 0.33 & $1.09 \mathrm{Bb}$ & $0.75 \mathrm{Aa}$ & $1.83 \mathrm{Ab}$ & $49.33 \mathrm{Bb}$ & $28.93 \mathrm{Aa}$ & $27.00 \mathrm{Bb}$ & $10.53 \mathrm{Bb}$ & $11.23 \mathrm{Bb}$ \\
\hline BR4101 (0) & 4 & 45.67 & $1.22 \mathrm{Ab}$ & $0.59 \mathrm{Aa}$ & $1.85 \mathrm{Ab}$ & $55.26 \mathrm{Ab}$ & $30.50 \mathrm{Aa}$ & $25.97 \mathrm{Bb}$ & 16.70 Ab & $14.13 \mathrm{Bb}$ \\
\hline $\mathrm{HN}\left(52.5 \mathrm{mg} \mathrm{N} \mathrm{L}^{-1}\right)$ & 0 & 0 & $2.20 \mathrm{Aa}$ & $1.00 \mathrm{Aa}$ & $3.20 \mathrm{Ab}$ & $100.02 \mathrm{Aa}$ & $35.07 \mathrm{Aa}$ & $35.93 \mathrm{Aa}$ & $25.53 \mathrm{Aa}$ & $55.17 \mathrm{Aa}$ \\
\hline LN (5.25 mg N L-1) & 0 & 0 & $0.88 \mathrm{Bb}$ & $0.80 \mathrm{Aa}$ & $1.68 \mathrm{Ab}$ & $39.85 \mathrm{Bb}$ & $27.23 \mathrm{Aa}$ & $23.57 \mathrm{Bb}$ & $12.23 \mathrm{Bb}$ & $10.34 \mathrm{Bb}$ \\
\hline
\end{tabular}

${ }^{*} \mathrm{~B}=$ Bradyrhizobium, $\mathrm{R}=$ Rhizobium, $\mathrm{O}=$ Ochrobactrum; ${ }^{\star *}$ Data followed by the same uppercase letter in the column do not differ from the HN treatment, and followed by the same lowercase letter in the column do not differ from the LN treatment; significant by the Dunnett test $(p<0.05)$. HN $=$ Control treatment with mineral nitrogen fertilization. $\mathrm{LN}=$ Control treatment without inoculation and with low mineral nitrogen content. 

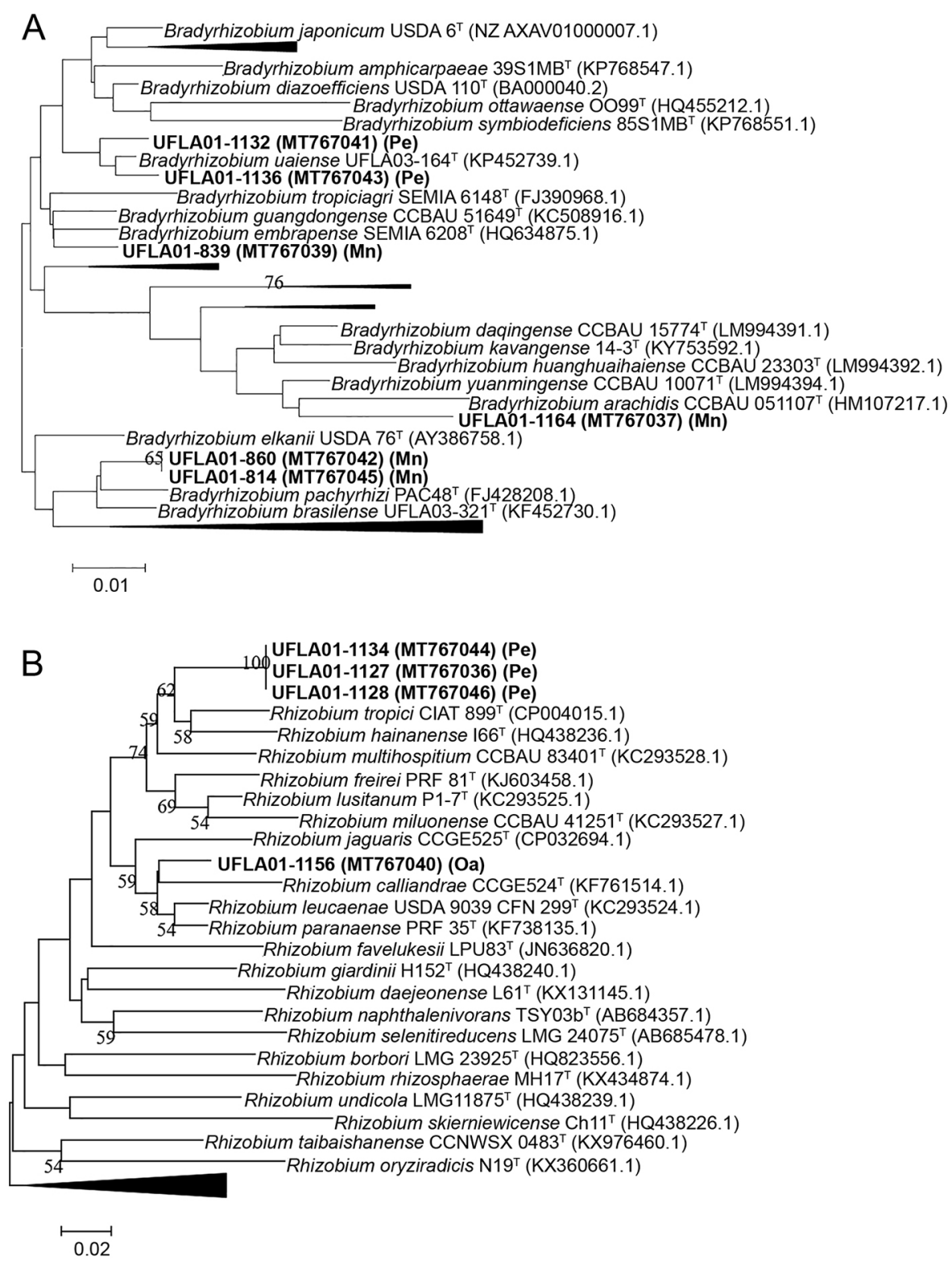

Figure 1 - Phylogenetic trees based on sequences of the gyrB gene of Bradyrhizobium (207 bp) (A) and Rhizobium (210 bp) (B) strains authenticated in regard to nodulating capacity in $M$. nyctitans $(\mathrm{Mn}), P$. elegans (Pe), and 0 . arborea (Oa) and type strains of known species exhibiting at least $95 \%$ similarity with the sequences studied (calculated by BLAST). (A) Phylogeny determined by the neighbor-joining and bootstrap method of 1000 replications. The designation (T) indicates biovar reference strains (former species type strain).

nearest species, B. daqingense CCBAU $15774^{\mathrm{T}}$, and the UFLA01-839 strain showed $99 \%$ similarity to the nearest species, $B$. viridifuturi SEMIA $690^{\mathrm{T}}$. The UFLA01814 and UFLA01-860 strains of $M$. nyctitans created a separate cluster, $65 \%$ bootstrap, which belong to the Bradyrhizobium elkanii superclade. This group had $96 \%$ similarity to the nearest species, B. pachyrhizi PAC $48^{\mathrm{T}}$. The UFLA01-1136 strain of $P$. elegans was at a phylogenetic position isolated from the other species, with greatest proximity to $B$. uaiense UFLA03-164 ${ }^{\mathrm{T}}$, with
$98 \%$ similarity. Finally, the UFLA01-1132 strain was positioned separately from all Bradyrhizobium species. Its closest species was $B$. diazoefficiens USDA $110^{\mathrm{T}}$, with $98.2 \%$ similarity.

From the $a t p D$ gene sequencing six strains of Rhizobium and two of Bradyrhizobium were identified (Figure 2A and B). Among the strains identified as Rhizobium, a similar response was observed for the strains UFLA 01-1128 and UFLA 01-1127 of P. elegans compared to the gyrB gene. These strains were nearer 

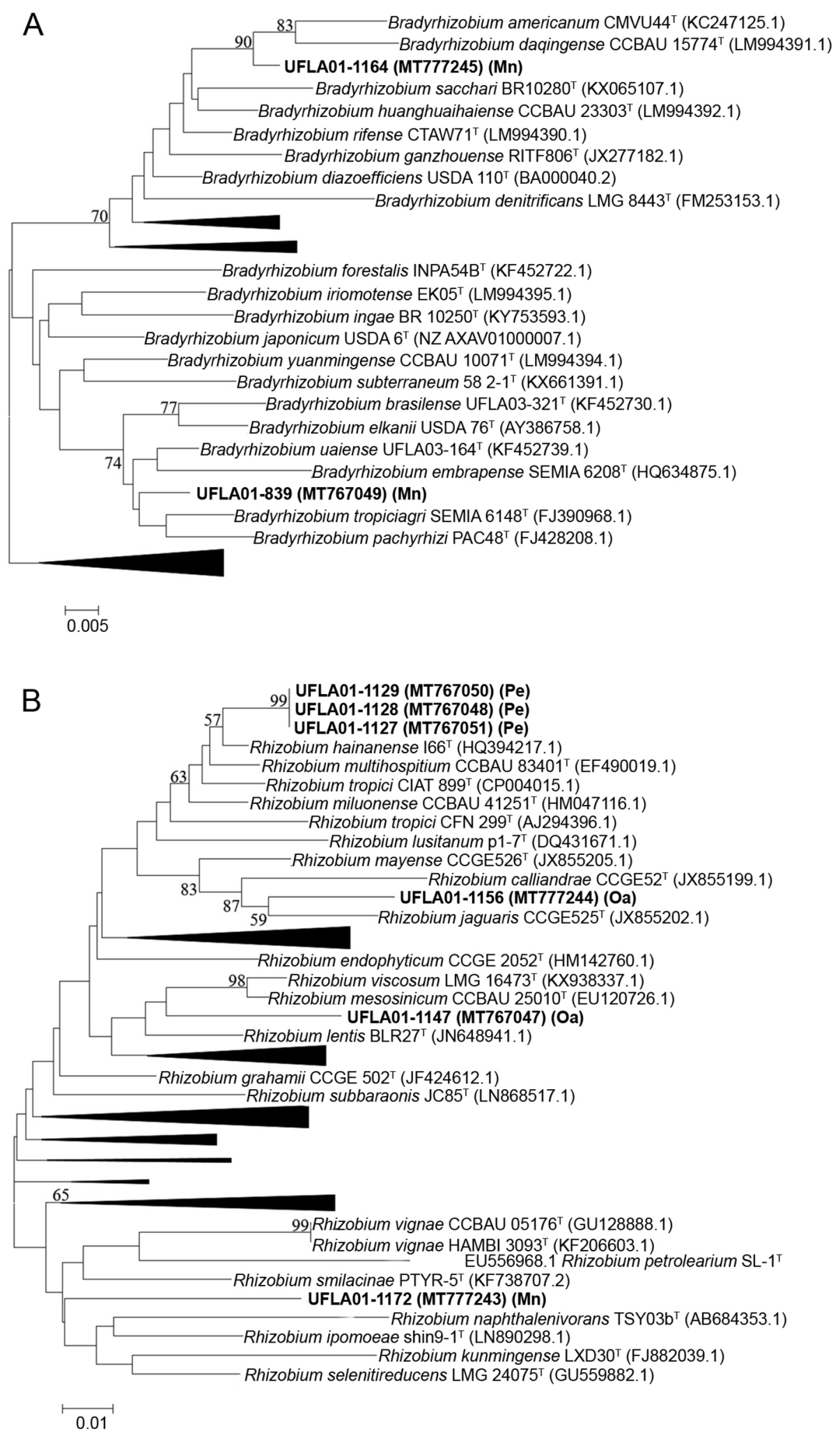

Figure 2 - Phylogenetic trees based on sequences of the atpD gene of Bradyrhizobium (352 bp) (A) and Rhizobium (336 bp) (B) strains authenticated in regard to nodulating capacity in $M$. nyctitans (Mn), P. elegans (Pe), and O. arborea (Oa) and 24 type strains of known species exhibiting at least $95 \%$ similarity with the sequences studied (calculated by BLAST). Phylogeny determined by the neighbor-joining and bootstrap method of 1000 replications. The designation (T) indicates biovar reference strains (former species type strain). 
to $R$. hainanense $\mathrm{I}^{6} 6^{\mathrm{T}}$, with $57 \%$ bootstrap and $99 \%$ similarity. The UFLA01-1156 strain of $O$. arborea was similar to $R$. jaguaris CCGE525 ${ }^{\mathrm{T}}$, with $59 \%$ bootstrap and $98 \%$ similarity; and the strain UFLA01-1147 of $O$. arborea was similar to $R$. lentis $\mathrm{BRL} 27^{\mathrm{T}}$ at $96 \%$ similarity. Among the strains identified as Bradyrhizobium, there was separate positioning of the strains UFLA011164 and UFLA01-839 of $M$. nyctitans, just as in the phylogenetic tree of the $\operatorname{gyr} B$ gene. However, in the phylogenetic tree of the $a t p D$ gene (Figure 2A), the UFLA01-1164 strain had greater similarity to $B$. americanum CMVU44 ${ }^{\mathrm{T}}$, with $90 \%$ bootstrap and 99 $\%$ similarity, and the UFLA01-839 strain had $99 \%$ similarity to $B$. tropiciagri SEMIA6148 ${ }^{\mathrm{T}}$.

In the phylogenetic tree of the nifH gene for seven out of the 11 strains that had this gene amplified (Figure 3), the strains of Bradyrhizobium UFLA01-814 and UFLA01-860 of $M$. nyctitans were clustered with greatest proximity to $B$. mercantei SEMIA6399 ${ }^{\mathrm{T}}$. The UFLA01839 of $M$. nyctitans and UFLA01-1136 of $P$. elegans are clustered but are separated from the other type strains from the Bradyrhizobium and Rhizobium genera. UFLA01874 of $P$. elegans and UFLA01-1172 and UFLA01-1164 of $M$. nyctitans were clustered with the greatest proximity to B. stylosanthis BR446 ${ }^{\mathrm{T}}$. All the clusters formed except UFLA01-839 and UFLA01-1136 are supported by high bootstrap values. Bradyrhizobium strains UFLA01-874 and UFLA01-1164 and Rhizobium UFLA01-1172 strain grouped together in a separate clade with high statistical support (98\%). This result elicits interest as it indicated a possible horizontal gene transfer.

\section{Discussion}

Although there was no response in plant dry matter, the contribution of nitrogen $\left(\mathrm{N}_{2}\right)$ fixed by the bacteria can be quantified by the SPAD index, which is indirectly related to the chlorophyll content in the plant shoots, depending on the intensity of green in the leaves. In the case of Machaerium plants, the SPAD index was able to show differences between the treatments before the increase in dry matter, proving to be a useful analysis for a short-term experiment. These data corroborate the data obtained by Jaramillo et al. (2013), who obtained a SPAD response before differentiation in dry matter in an experiment on inoculation efficiency in Vigna unguiculata (cowpea). In addition, there was positive correlation of the SPAD index with SNC, which made

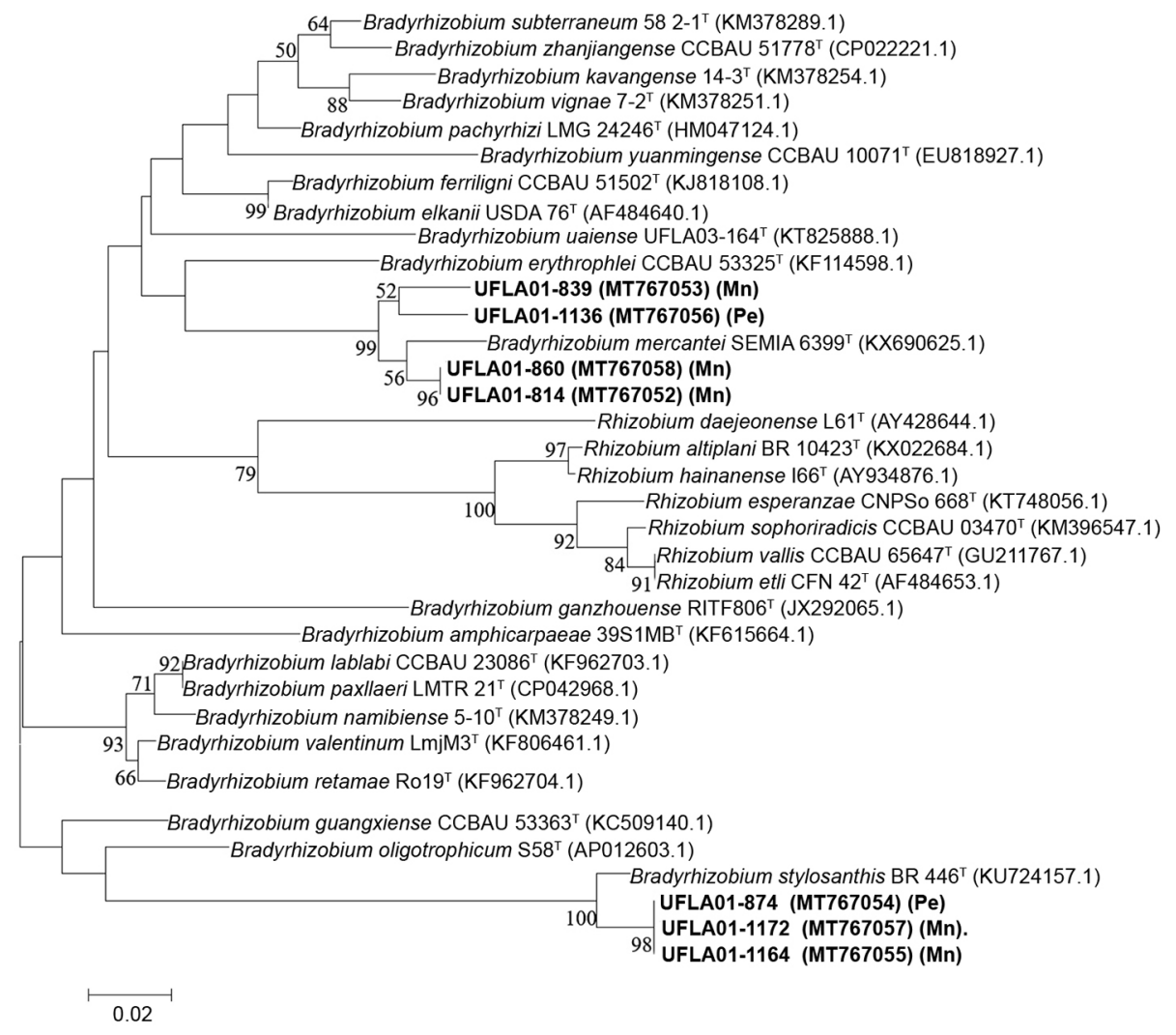

Figure 3 - Phylogenetic tree based on sequences of the nifH (205 bp) gene of 7 strains authenticated in regard to nodulating capacity in $M$. nyctitans (Mn) and P. elegans (Pe) and 28 type strains of known species exhibiting at least $95 \%$ similarity with the sequences studied (calculated by BLAST). Phylogeny determined by the neighbor-joining and bootstrap method of 1000 replications. The designation (T) indicates biovar reference strains (former species type strain). 
it possible to use the values of this index as a rapid response in relation to shoot $\mathrm{N}$ content. Nyoki and Ndakidemi (2014) also cite the benefits of inoculation with rhizobia and their effect on chlorophyll formation, corroborating the data obtained in this study.

Pastorini et al. (2016) found no nodules on plants of Machaerium brasilense Vogel without inoculation at 90 days after transplanting to a substrate composed of a mixture of commercial organic substrate and sand (1:2). Nodules were observed only 180 days after transplanting. Nevertheless, in this study, nodulation of the Macherium nyctitans plants was found at 60 days after transplanting, showing that through the inoculation process, it is possible to advance rhizobia symbiosis in the seedlings. The two strains of $P$. elegans that did not nodulate this species may be invasive bacteria, endophytic bacteria of the nodule, noduleforming bacteria that are not specific for this species, or nodule-forming bacteria that failed to encounter conditions favorable to their nodulation. One of the conditions necessary for nodulation may be related to the point in time of inoculation, i.e., if inoculation is performed at the time of sowing, the time at which the seedling will require nitrogen (at deficiency) should be ascertained because if the seedling still has seed reserves, it will not need to establish symbiosis and will not produce signaling flavonoids that will activate expression of the nod genes of rhizobia, which may render the nodulation process inviable (Ndakidemi and Dakora, 2003). This delay in establishing symbiosis may be reflected in late responses in the efficiency tests, taking into consideration that the experiments were conducted in 60, 90, and 150 days in a greenhouse. Thus, certain forest species require a longer time for conducting the experiment up to evaluation. If the difference between each treatment and the control without inoculation with low mineral-N content fails to produce significant differences in the vegetative growth parameters evaluated, then it is necessary for the plants to be subjected to a longer time of exposure to the treatments so that the resultant differences will be significant. In addition, low nodulation or absence of it should be carefully observed, since microorganisms present in identifiable systems can perform another type of process that promotes vegetative growth, such as solubilization of phosphate and production of phytohormones (Costa et al., 2016).

The two superclades of Bradyrhizobium (B. elkanii and B. japonicum) are well defined phylogenetically (Avontuur et al., 2019). Strains representative of the two superclades isolated from $M$. nyctitans and $P$. elegans were authenticated, whereas from $O$. arborea, the only strain of Bradyrhizobium authenticated belonged to the $B$. elkanii superclade. Identification of strains forming different clusters in these two clades, or only separating themselves in an isolated manner from the other type species within the phylogenetic trees of the housekeeping genes (atpD and gyrB), separated or concatenated, with similarity values below $95 \%$, indicates the possibility of new species not yet described. In a study describing a new species of Bradyrhizobium, Costa et al. (2018) found similarity values of 96-93 and 97-95\% between type species and the strains tested when they analyzed sequences of housekeeping genes $(a t p D$ and gyr $B)$. These values were also found our study, thereby corroborating the identification of possible new species. The Bradyrhizobium strain UFLA01-839, which is among those with the potential for being a new species, stood out in the authentication and symbiotic efficiency experiment with $M$. nyctitans, and it can be considered for future tests of selection of inoculant strains for this forest species. Although, no final conclusions can be formed about specificity of these tree species regarding rhizobia genera, it is noteworthy that the highest affinity of $M$. nyctitans with Bradyrhizobium and of P. elegans was with Rhizobium.

The results obtained from phylogenetic analysis of the housekeeping genes performed in this study corroborate other studies, which show that sequencing of housekeeping genes improves discrimination of species of both Bradyrhizobium and Rhizobium, complementing the analysis of the $16 \mathrm{~S}$ rRNA gene (Guimarães et al., 2015; Bourebaba et al., 2016; Rouhrazi et al., 2016; Degefu et al., 2017). In addition, results show that the gyrB gene is useful in discriminating species, as shown by Guimarães et al. (2015). This type of analysis was efficient in separating strains with greater potential for being new taxons. However, new studies that involve more comprehensive analyses of the genome of these microorganisms have become increasingly necessary for description of species (Konstantinidis and Tiedje, 2005; López-Guerrero et al., 2012; Okazaki et al., 2015; Kishi et al., 2016; Costa et al., 2018).

The high diversity found among strains isolated from the different forest species show how necessary it is to select specific strains for each one of them. This can be seen in various studies that tested Mimosa spp. inoculated with Burkholderia (Araújo et al., 2017) or Inga sp. inoculated with Bradyrhizobium (Silva et al., 2014; Porto et al., 2017). They exhibit different plant/ microorganism combinations, reaffirming the need for determining which combinations are most efficient.

In addition, another important factor in the description of new species is their phylogenetic relationship based on symbiotic genes such as nifH. Horizontal transfer of these genes represents an important tool in the evolutionary force, which is able to confer adaptive advantages to determined rhizobia species (Parker, 2012; Remigi et al., 2016). There were strains both with and without affinity between the phylogenies of the nifH gene and the housekeeping genes. Thus, we can advance the hypothesis that there may have been both vertical and horizontal transmission of the nifH gene between the strains studied (Michel et al., 2020). 


\section{Conclusions}

Nodulation of the three forest species was confirmed in 16 of their strains of origin, belonging to both Rhizobium and Bradyrhizobium. Phylogenetic analysis of the $\operatorname{atp} D$ and $\operatorname{gyr} B$ housekeeping genes indicated high diversity in Rhizobium and Bradyrhizobium strains with the potential for representing new species, such as UFLA01-1127, UFLA01-1128, UFLA01-1129, UFLA011134, UFLA01-1156, UFLA01-1172 in Rhizobium, and UFLA01-814, UFLA01-839, UFLA01-860, UFLA011164 and UFLA01-1132 in Bradyrhizobium.

Inoculation of the UFLA01-839 (Bradyrhizobium sp.) strain into the Machaerium nyctitans seedlings resulted in more efficient symbiosis. It was not possible to ascertain the symbiotic efficiency of the strains in Platypodium elegans and Ormosia arborea, probably due to the greater amount of energy reserves of the seeds, which supplied the demand of the seedlings in the present study. Therefore, a longer evaluation time for these species is recommended in future studies.

The SPAD index was efficient in detecting efficiency in fixing $\mathrm{N}_{2}$ before the determination of shoot dry matter.

Identification and characterization of the 18 strains of rhizobia will allow them to be studied in future research to test their symbiotic efficiency under axenic conditions, as well as to identify them at species level by genome sequencing allowing advancement in the development of new inoculants for forest species.

\section{Acknowledgments}

The authors thank CNPq (Brazilian National Council for Scientific and Technological Development), CAPES (Coordination for the Improvement of Higher Level Personnel) and FAPEMIG (Minas Gerais State Agency for Research and Development) for funding (CNPq 431504/2016-4, FAPEMIG-CAG-RED-00330-16; CAPES/ PROEX/UFLA/PPGCS AUXPE 593/2018), granting scholarships for undergraduate scientific research (CNPq - A.M. Costa and B.L.M. Duarte; UFLA M.S. Pereira), Master's degree studies (FAPEMIG - B.D. Lopez; CAPES - J.S. Costa), Doctoral studies (FAPEMIG - A.F.S. Teixeira; CAPES - D.C. Michel), and Post-doctoral studies CAPES - A.A. Guimarães), and funding for research productivity fellowship (CNPq Processes: 304527/2016-5 - F.M.S. Moreira). This research is associated with the Brazilian National Institute of Science and Technology (Soil Biodiversity/ INCT - CNPq).

\section{Authors' Contributions}

Conceptualization: Lopez, B.D.O.; Moreira, F.M.S.; Guimarães, A.A. Data acquisition: Lopez, B.D.O.;
Teixeira, A.F.S.; Duarte, B.L.M.; Pereira, M.S.; Michel, D.C.; Costa, J.S.; Costa, A.M. Data analysis: Lopez, B.D.O.; Michel, D.C.; Moreira, F.M.S. Design of methodology: Lopez, B.D.O.; Teixeira, A.F.S.; Guimarães, A.A.; Moreira, F.M.S. Writing and editing: Lopez, B.D.O.; Teixeira, A.F.S.; Michel, D.C.; Guimarães, A.A.; Moreira, F.M.S.

\section{References}

Araújo, K.S.; Carvalho, F.; Moreira, F.M.S. 2017. Bukholderia strains promote Mimosa spp. growth but not Macroptilium atropurpureum. Revista Ciência Agronômica 48: 41-48.

Avontuur, J.R.; Palmer, M.; Beukes, C.W.; Chan, W.Y.; Coetzee, M.P.A.; Blom, J.; Stepkowski, T.; Kyrpides, N.C.; Woyke, T.; Shapiro, N.; Whitman, W.B.; Venter, S.N.; Steenkamp, E.T. 2019. Genome-informed Bradyrhizobium taxonomy: where to from here? Systematic and Applied Microbiology 42: 427-439.

Bourebaba, Y.; Durán, D.; Boulila, F.; Ahnia, H.; Boulila, A.; Temprano, F.; Palacios, J.M.; Imperial, J.; Ruiz-Argüeso, T.; Rey, L. 2016. Diversity of Bradyrhizobium strains nodulating Lupinus micranthus on both sides of the western Mediterranean: Algeria and Spain. Systematic Applied Microbiology 39: 266-274.

Costa, E.M.; Carvalho, F.; Nóbrega, R.S.A.; Silva, J.S.; Moreira, F.M.S. 2016. Bacterial strains from floodplain soils perform different plant-growth promoting processes and enhance cowpea growth. Scientia Agricola 73: 301-310.

Costa, E.M.; Guimarães, A.A.; Carvalho, T.S.; Rodrigues, T.L.; Ribeiro, P.R.A.; Lebbe, L.; Willems, A.; Moreira, F.M.S. 2018. Bradyrhizobium forestalis sp. nov., an efficient nitrogen-fixing bacterium isolated from nodules of forest legume species in the Amazon. Archives of Microbiology 200: 743-752.

Degefu, T.; Wolde-meskel, E.; Woliy, K.; Frostegård, Å. 2017. Phylogenetically diverse groups of Bradyrhizobium isolated from nodules of tree and annual legume species growing in Ethiopia. Systematic and Applied Microbiology 40: 205-214.

Edgar, R.C. 2004. Muscle: a multiple sequence alignment method with reduced time and space complexity. BMC Bioinformatics 5: 113.

Faria, S.M.; Uchôa, E.S. 2007. Indication of Rhizobium Strains Efficient in Biological Nitrogen fixation for multiple use species: updated base year 2006 = Indicação de estirpes de rizóbio eficientes na fixação biológica de nitrogênio para espécies de múltiplo uso: Atualização ano base 2006. Available at: https://ainfo.cnptia.embrapa.br/digital/ bitstream/CNPAB-2010/34394/1/doc228.pdf [Accessed Oct 15, 2016] (in Portuguese).

Faria, S.M.; Lewis, G.P.; Sprent, J.I.; Sutherland, J.M. 1989. Occurrence of nodulation in the Leguminosae. New Phytologist 111: 607-619.

Fred, E.B.; Waksman, S.A. 1928. Laboratory Manual of General Microbiology. McGraw-Hill, New York, NY, USA.

Gaunt, M.W.; Turner, S.L.; Rigottier-Gois, L.; Lloyd-Macgilp, S.A.; Young, J.P.W. 2001. Phylogenies of atpD and recA support the small subunit rRNA-based classification of rhizobia. International Journal of Systematic and Evolutionary Microbiology 51: 2037-2048. 
Guimarães, A.A.; Florentino, L.A.; Almeida, K.A.; Lebbe, L.; Silva, K.B.; Willems, A.; Moreira, F.M.S. 2015. High diversity of Bradyrhizobium strains isolated from several legume species and land uses in Brazilian tropical ecosystems. Systematic and Applied Microbiology 38: 433-441.

Guimarães, A.A.; Jaramillo, P.M.D.; Nóbrega, R.S.A.; Florentino, L.A.; Silva, K.B.; Moreira, F.M.S. 2012. Genetic and symbiotic diversity of nitrogen-fixing bacteria isolated from agricultural soils in the western Amazon by using cowpea as the trap plant. Applied and Environmental Microbiology 78: 6726-6733.

Hoagland, D.R.; Arnon, D.I. 1950. The Water Culture Method for Growing Plant without Soil. California Agricultural Experimental Station, Berkeley, CA, USA.

Jaramillo, P.M.D; Guimarães, A.A.; Florentino, L.A.; Silva, K.B.; Nóbrega, R.S.A.; Moreira, F.M.S. 2013. Symbiotic nitrogen-fixing bacterial populations trapped from soils under agroforestry systems in the Western Amazon. Scientia Agricola 70: 397-404.

Ken, A. 2020. Asbio: a collection of statistical tools for biologists. $R$ package version 1.6-3. Available in: https://CRAN.R-project.org/ package $=$ asbio $[$ Accessed May 12, 2020]

Kimura, M. 1980. A simple method for estimating evolutionary rates of base substitutions through comparative studies of nucleotide sequences. Journal of Molecular Evolution 16: 111-120.

Kishi, L.T.; Fernandes, C.C.; Omori, W.P.; Campanharo, J.C.; Lemos, E.G.M. 2016. Reclassification of the taxonomic status of SEMIA3007 isolated in Mexico B-11A Mex as Rhizobium leguminosarum bv. viceae by bioinformatic tools. BMC Microbiology 16: 1-8.

Kirk, P.L. 1950. Kjeldahl Method for total nitrogen. Analytical Chemistry 22: 354-358.

Konstantinidis K.T.; Tiedje, J.M. 2005. Genomic insights that advance the species definition for prokaryotes. Proceedings of the National Academy of Sciences 7: 2567-2572.

Kumar, S.; Stecher, G.; Tamura, K. 2016. MEGA7: Molecular evolutionary genetics analysis version 7.0 for bigger datasets. Molecular Biology Evolution 33: 1870-1874.

López-Guerrero, M.G.; Ormeño-Orrillo, E.; Velázquez, E.; Rogel, M.A.; Acosta, J.L.; Gónzalez, V.; Martínez, J.; Martínez-Romero, E. 2012. Rhizobium etli taxonomy revised with novel genomic data and analyses. Systematic and Applied Microbiology 35: 353-358.

Martens, M.; Delaere, M.; Coopman, R.; Vos, P.; Gillis, M.; Willems, A. 2007. Multilocus sequence analysis of Ensifer and related taxa. International Journal of Systematic and Evolutionary Microbiology 57: 489-503.

Mendiburu, F. 2017. Agricolae: statistical procedures for agricultural research. Available at: https://CRAN.R-project.org/ package $=$ agricolae $[$ Accessed May 12, 2020]

Michel, D.C.; Guimarães, A.A.; Costa, E.M.; Carvalho, T.S.; Balsanelli, E.; Willems, A.; Souza, E.M.; Moreira, F.M.S. 2020. Bradyrhizobium uaiense sp. nov., a new highly efficient cowpea symbiont. Archives of Microbiology 202: 1135-1141.

Ministério da Agricultura, Pecuária e Abastecimento [MAPA]. 2011. Normative instruction SDA n. 13, of March 24 = Instrução normativa DAS n. 13, de 24 de março. 2011. Available at: https:// www.gov.br/agricultura/pt-br/assuntos/insumos-agropecuarios/ insumos-agricolas/fertilizantes/legislacao/in-sda-13-de-24-03-2011inoculantes.pdf/view [Accessed May 12, 2020] (in Portuguese).
Moreira, F.M.S.; Silva, M.F.; Faria, S.M. 1992. Occurrence of nodulation in legume species in the Amazon region of Brazil. New Phytologist 121: 563-570.

Moreira, F.M.S.; Siqueira, J.O. 2006. Soil Microbiology and Biochemistry $=$ Microbiologia e Bioquímica do Solo. Editora UFLA, Lavras, MG, Brazil (in Portuguese).

Moreira, F.M.S. 2008. Nitrogen-fixing Leguminosae nodulating Bacteria. p. 107-130. In: Moreira, F.M.S.; Huising, E.J.; Bignell, D.E., eds. Handbook of tropical soil biology: sampling and characterization of below-ground biodiversity. Earthscan, London, UK.

Ndakidemi, P.A.; Dakora, F.D. 2003. Legume seed flavonoids and nitrogenous metabolites as signals and protectants in early seedling development. Functional Plant Biology 30: 729-745.

Nyoki, D.; Ndakidemi, P.A. 2014. Effects of Bradyrhizobium japonicum and phosphorus supplementation on the productivity of legumes. International Journal of Plant and Soil Science 3: 894-910.

Okazaki, S.; Noisangiam, R.; Okubo, T.; Kaneko, T.; Oshima, K.; Hattori, M.; Teamtisong, K.; Songwattana, P.; Tittabutr, P.; Boonkerd, N. 2015. Genome analysis of a novel bradyrhizobium sp. doa9 carrying a symbiotic plasmid. PLoS One 10: e0117392.

Oliveira, A.F.; Neves, C.L.P.; Pereira, G.A.; Garcia, F.H.S.; Coelho, S.J.; Pereira, J.A.A. 2018. Floristics of road forestry conflicting with the electrical networks: a case study in the southern region of Minas Gerais State. Ornamental Horticulture 24: 277-284

Parker, M.A. 2012. Legumes select symbiosis island: sequence variants in Bradyrhizobium. Molecular Ecology 21: 1769-1778.

Pastorini, L.H.; Romagnolo, M.B.; Barbeiro, C.; Oliveira Guerreiro, R.G.; Costa, P.M.; Sert, M.A.; Souza, L.A. 2016. Germination and initial growth of Machaerium brasiliense Vogel (Fabaceae) in a greenhouse. Floresta 46: 83-92 (in Portuguese, with abstract in English).

Pena, E.; Slate, E. 2006. Global validation of linear model assumptions. Journal of the American Statistical Association 101: 341-354.

Porto, D.S.; Farias, E.N.C.; Chaves, J.S.; Souza, B.F.; Medeiros, R.D.; Zilli, J.É.; Silva, K. 2017. Symbiotic effectiveness of Bradyrhizobium ingae in promoting growth of Inga edulis Mart. Seedlings. Revista Brasileira de Ciência do Solo 41: 1-15.

Remigi, P.; Zhu, J.; Young, J.P.W.; Masson-Boivin, C. 2016. Symbiosis within symbiosis: evolving nitrogen-fixing legume symbionts. Trends in Microbiology 24: 63-75.

Rösch, C.; Mergel, A.; Bothe, H. 2002. Biodiversity of denitrifying and dinitrogen-fixing bacteria in an acid forest soil. Applied and Environmental Microbiology 68: 3818-3829.

Rouhrazi, K.; Khodakaramian, G.; Velázquez, E. 2016. Phylogenetic diversity of rhizobial species and symbiovars nodulating Phaseolus vulgaris in Iran. FEMS Microbiology Letters 363: 1-8.

Sá, O.A.A.L.; Ribeiro, P.R.A.; Rufini, M.; Cruvinel, A.F.; Casagrande, D.R.; Moreira, F.M.S. 2019. Microsymbiont of forage peanut under different soil and climate conditions belong to a specific group of Bradyrhizobium strains. Applied Soil Ecology 143: 201212.

Saitou, N.; Nei, M. 1987. The neighbor-joining method: a new method for reconstructing phylogenetic trees. Science 4: 406425 . 
Sarita, S.; Sharma, P.K.; Priefer, U.B.; Prell, J. 2005. Direct amplification of rhizobial nodC sequences from soil total DNA and comparison to nodC diversity of root nodule isolates. FEMS Microbiology Ecology 54: 1-11.

Sattler, D.; Raedig, C.; Hebner, A.; Wesenberg, J. 2018. Use of native plant species for ecological restoration and rehabilitation measures in southeast Brazil. p. 191-204. In: Nehren, U.; Schlüter, S.; Raedig, C.; Sattler, D.; Hissa, H., eds. Strategies and tools for a sustainable rural Rio de Janeiro. Springer, Cham, Switzerland.

Silva, A.R.; Malafaia, G.; Menezes, I.P.P. 2017. Biotools: an R function to predict spatial gene diversity via an individual-based approach. Genetics and Molecular Research 16: gmr16029655.

Silva, E.D.; Tozzi, A.G.A.; Meireles, L.D. 2015. Distribution of Leguminosae tree species in different altitudinal levels along the Atlantic Rain Forest in the Brazilian coast. Journal of Systematics and Evolution. 53: 266-279.

Silva, K.; Meyer, S.E.; Rouws, L.F.M.; Farias, E.N.C.; Santos, M.A.O.; O'Hara, G.; Ardley, J.K.; Willems, A.; Pitard, R.M.; Zilli, J.E. 2014. Bradyrhizobium ingae sp. nov., isolated from effective nodules of Inga laurina grown in Cerrado soil. International Journal of Systematic and Evolutionary Microbiology 64: 33953401.
Sprent, J.I.; Parsons, R. 2000. Nitrogen fixation in legume and nonlegume trees. Field Crop Research 65: 183-196.

Sterner, J.P.; Parker, M.A. 1999. Diversity and relationships of bradyrhizobia from Amphicarpaea bracteata based on partial nod and ribosomal sequences. Systematic and Applied Microbiology 2: 387-392.

Vale, V.S.; Prado Júnior, J.A.; Lopes, S.F.; Arantes, C.S.; Nascimento, D.R.; Dias-Neto, O.C.; Gusson, A.E.; Santos, L.C.S.; Schiavini, I. 2018. Changes in soil moisture and riparian forest structure after a dam construction. Iheringia 73: 250-260.

Zou, L.; Chen, Y.X.; Penttinen, P.; Lan, Q.; Wang, K.; Liu, M.; Peng, D.; Zhang, X.; Chen, Q.; Zhao, K.; Zeng, X.; Xu, K.W. 2016. Genetic diversity and symbiotic efficiency of nodulating rhizobia isolated from root nodules of Faba bean on one field. Plos One 11: e0167804. 